sense of humor and wit sparkled in the classroom. Martz influenced numerous undergraduates to choose careers that took them to Latin America; in business, government, and the academy. His graduate students teach at some of the finest universities in the United States, Europe, and Latin America. Without exception, students remember John as a mentor who guided their professional development and cared about them as individuals.

He received grants and fellowships from the National Science Foundation, the Agency for International Development, the Fulbright Commission, the Guggenheim Committee, and the Raul Leoni Foundation. Penn State recognized Martz's path-breaking research with a Social and Behavioral Sciences Faculty Scholar Medal and in 1991 named him Distinguished Professor of Political Science.

Professor Martz is survived by his wife, Corazon Cruz Martz of State College; a son, David Sobrepena of Abbotsford, British Columbia; a daughter, Joy Sobrepena Wagner of Orlando, Florida; and three grandchildren.

A memorial service was held on Friday, September 18, in the Helen Eakin Eisenhower Chapel at Penn State University Park. During the reception that followed, friends from all walks of life remembered John as wise, affectionate, amusing, and loyal. His untimely passing is a great loss.

The department of political science has established a fund in John's memory to assist Penn State graduate and undergraduate students with international educational travel. Contributions to this fund may be made to The John Martz Memorial Fund in Political Science, Alumni Relations \& Development, Pennsylvania State University, 101 Sparks Building, University Park, PA 16802. The Latin American Studies Association has also established a fund in John's memory to assist Latin American scholars with travel to the United States. Contributions to this fund may be made to John Martz Fund-LASA, Latin American Studies Association Secretariat, William Pitt Union,
Room 946, University of Pittsburgh, Pittsburgh, PA 15260.

David J. Myers

Penn State University

\section{Emmette Redford}

I write to honor Emmette Shelburn Redford as a great teacher, an eminent scholar, and a dedicated public servant. But even more as a dear friend and colleague. Let it be stated for the record that he died on January 30, 1998, in Austin, Texas, and that he is buried in the Austin Memorial Park on Hancock Drive. I write to celebrate his life, acknowledge his death, and wish him godspeed.

Emmette Redford was born in San Antonio, Texas, on September 23,1905 , and grew up in Johnson City, Texas, where he was a young friend of a still younger Lyndon Johnson. One of Emmette's favorite stories of his boyhood was of the day when he was charged with taking care of his younger brothers Clarence and Cecil, and also their young neighbor Lyndon. Lyndon got out of line somehow and Emmette administered a spanking. I heard him tell that story several times, but I doubt if he ever got around to telling it to the president of the United States.

I shall always have a special spot in my heart for Emmette Redford. He was the department chairman who hired me and brought me to Texas, and ever afterwards I have been grateful to him and have always admired his judgment. So Emmette, wherever you are, if you disagree with anything I say about you here, you have only yourself to blame. Emmette seems to have been a solemn, earnest boy, who tyrannized over his younger brothers. He sold pots and pans from door to door. He also worked for his mother, who was postmistress of Johnson City, and he was sworn in as a U.S. postal clerk at the age of twelve. This taught him at an early age something of importance about both public administration and nepotism.

Emmette went to two or three schools during his younger years, but he never graduated from high school. In 1922 he entered the University of Texas, and I might observe that in these days he would not be admitted-which is likely true for several of us. He received a B.A. in 1927, an M.A. in 1928, and a Ph.D. at Harvard in 1933. After that he came back to the University of Texas and stayed there ever afterwards, give or take a visiting appointment here and there, a few government posts, and the intrusion of a war or two. He progressed straight through the ranks to full professor, department chairman, and ultimately to the Ashbel Smith Professorship of Government and Public Affairs.

During the Second World War he worked for the Office of Price Administration in Dallas, and later in Washinigton, and he wrote a book about his experience. Indeed, he went on to write another eight or ten books, many of which commanded their fields and were regarded as the exemplary analyses of particular problems of public life.

At the university, he was a very active member of the academic community. He was an inveterate committee person, served repeatedly on the University Council, and at one time held the chair of a key committee charged with the task of recommending a core curriculum for all degree programs. It proved to be a hopeless task, and I remember very well the day when the university faculty met to receive his report. During the course of the afternoon, department after department demanded that its particular courses be included in the core curriculum, and the end result was that the faculty rejected his committee's recommendations overwhelmingly. Emmette simply grinned his famous grin of his and went back to work.

I learned a lesson from Emmette Redford that has molded my own life ever since, rather more than I ever intended. He said he always thought a man should be an active member of any community of which he happened to be a part. He exemplified that proposition in his own life, and I, myself, have tried to pass it on to later generations of students.

As a member of the faculty and the university community, Emmette 
was held in great esteem and affection by his colleagues. He received a Presidential Citation from UT President Robert Berdahl in 1996, one of a small handful of faculty members ever to be so honored. He was president of University Co-op for a quarter of a century, and a member of the governing body of the Interscholastic League for 33 years. He was elected and reelected to various councils and committees, and in 1987 he was designated as a distinguished alumnus of the University of Texas.

I think of Emmette principally as a colleague, mentor, and friend, but he was also a dedicated and helpful teacher and he gave endless time and concern to his students, especially to his graduate students. Two of his graduate students established a Redford Prize in the government department, and two of his undergraduate students established a Redford Prize in the LBJ School while he, himself, established a special fund to help needy students in the LBJ School.

Redford's world was public administration and the making of public policy. Indeed he helped make that world. It was Redford as much as any other scholar who taught political scientists that the administrative process, no less than the legislative process, is subject to interestgroup pressures and controls. It was Redford as much as any other political scientist who refocused the concerns of the discipline on public policy. It was Redford as much as any other scholar who erected the public interest as the criterion and objective of policy-making. It was Redford as much as any other political scientist who taught the lawyers that administrative law was the artifact of a political process. Emmette achieved national and international distinction as a scholar. His research and writing were always addressed to the major problems of the nation, especially in the management of the economy; and his books were invariably well received. He was an active member of the American Society for Public Administration and the American Political Science Association, of which he became president in 1960 .
About the time Emmette was thinking of retiring, his grandchildren came to live with him and his wife, Claire. That generated a whole new life and career, and a new beginning as a parent, let alone a grandparent, and he seized upon it with his customary gusto. Once again he lived in the world of the PTA, report cards, driving kids to events-the whole works. At one point, he took on the job of little league coach-with a somewhat marginal success. He would tell the boys to get down low on grounders, and he took them out to eat pizza. It turned out, however, that his coaching skills ran mostly to pizza buying and character building. The team, as I remember, was 0 and 7 on the year.

But the thing I remember best about Emmette Redford was that he and I shared a year-long effort to plan the development of the Lyndon Johnson School of Public Affairs. It was an exhilarating, gratifying, and sometimes frustrating experience, and then, when we completed the plans, a smaller group of us were charged to make a budget and find a dean. It was finally brought into being in 1970 with about 23 students. It has now grown to about ten times that size.

In 1975 Emmette decided to retire, but it didn't really take. He did it by starting an entirely new career teaching in the LBJ School itself. His colleagues spent a lot of money on a retirement party for him, including a half-naked dancing girl, but it was all wasted. He ceased to teach in the government department, but he launched a whole new career as a teacher in the LBJ School. In that role he helped shape the curriculum that he had previously helped to plan. So if we seek a monument for Redford, we have only to look about us, and to reflect that here was a man who planned carefully, administered thoughtfully, and put his plans and principles to a very practical use.

A few years after Emmette became a faculty member in the LBJ School, Harry Middleton and I took him out to lunch one day. By previous and devious design, we pressed upon him the idea that the time had come for somebody to write an ad- ministrative history of the Johnson administration, and we wanted him to tell us whom we might approach to do it. As you can guess, the luncheon ended by Emmette's agreeing to take on the task. He thought he was going to write a book, but it turned out that he not only did that, but took on a considerable task of research administration. The administrative study of the Johnson years finally came to eight or ten volumes, all produced under his authorship or leadership.

Emmette was never solemn about his life or work. He had a nice sense of humor, and he enjoyed many of the absurdities the human condition. Indeed, now and then he created a few himself, and relished the opportunity. There were many Redfords: the teacher, the colleague, the committee man, the planner, the scholar, and the national practitioner. But I remember him best and value him most as a colleague and as a friend. In many ways he will always be with us in the department, in the school, and in the university. But the truth is that he's gone, and there's no way and no reason to avoid saying, "We'll miss you, Emmette. We thank you and we wish you well." William Livingston University of Texas

\section{Rene de Visme Willamson}

Rene de Visme Willamson, professor emeritus of political science at Louisiana State University, died on July 8, 1998. Williamson was a Harvard Ph.D. who held faculty positions at Princeton, Davidson, Beloit, and the University of Tennessee before coming to LSU. He also taught at Johns Hoipkins, Duke, Vanderbilt, and the University of Michigan. He published several books, including Independence and Involvement: A Christian ReOrientation in Political Science and Politics and Protestant Theology: An Interpretation of Tillich, Barth, Bonhoeffer, and Brunner, and a number of articles in leading journals. A marvelous teacher, Dr. Williamson was one of the leading political theorists of his generation, particularly in the field of political theology. He served as editor of the Journal 